\title{
PENGARUH PENGEMBANGAN KARIR TERHADAP KINERJA PEGAWAI KEMENTERIAN PEKERJAAN UMUM BALAI BESAR WILAYAH SUNGAI MESUJI SEKAMPUNG DI BANDAR LAMPUNG
}

\author{
Yuliana Yamin ${ }^{(1)}$, Mariyah ${ }^{(2)}$ \\ Fakultas Ekonomi Universitas Sang Bumi Ruwa Jurai \\ yuliana.yamin@fe.saburai.ac.id,ariyah_09@gmail.com
}

\begin{abstract}
Abstrak. Sejalan dengan perkembangan suatu organisasi, maka diperlukan usaha-usaha untuk meningkatkan keterampilan dan profesionalisme pegawai dalam memberikan perhatian dan pembinaan yang pada akhirnya diharapkan dapat mengembangkan karir pegawai. Obyek pada penelitian ini adalah pegawai pada kantor Balai Besar Wilayah Sungai Mesuji Sekampung, berdasarkan hasil observasi yang penulis lakukan ditemukan fakta bahwa kinerja pegawai masih rendah, hal ini terlihat dari pencapaian target yang tidak terealisir secara keseluruhanTujuan penelitian ini adalah untuk mengetahui ada tidaknya pengaruh pengembangan karir terhadap kinerja. Hipotesis yang diajukan adalah ada pengaruh pengembangan karir terhadap kinerja pegawai Balai Besar Wilayah Sungai Mesuji Sekampung .Sampel yang digunakan sebanyak 53 pegawai. Pengolahan data primer dengan pendekatan metode analisis kuantitatif dibantu alat statistik aplikasi program SPSS versi 21.0. untuk perhitungan uji validitas, uji reliabilitas, uji regresi linier sederhana dan uji koefisien determinasi. tujuan penelitian yang berbunyi untuk mengetahui besarnya pengaruh pengembangan karir terhadap kinerja pegawai dapat diwujudkan dengan besarnya kontribusi antara pengembangan karir terhadap kinerja pegawai sebesar 32,2\%.
\end{abstract}

Kata kunci: Karir,Pegawai, Kinerja, Disiplin.

\section{PENDAHULUAN}

Perkembangan sosial ekonomi dunia serta era keterbukaan dan globalisasi, menuntut setiap organisasi untuk bersikap lebih responsif terhadap faktor perubahan eksternal untuk mampu bertahan dan terus berkembang. Sejalan dengan dinamika perubahan tersebut, maka diperlukan adanya perubahan individu sebagai elemen dari keseluruhan organisasi. Proses menyelaraskan perubahan organisasi dengan perubahan individu ini tidaklah mudah, oleh karenanya pemimpin sebagai pengendali dalam organisasi harus dapat menjadi pelopor, sehingga perubahan harus dimulai dari tingkat yang paling atas yaitu pemimpin itu sendiri.
Sumber daya manusia mempunyai fungsi yang penting dalam pencapaian visi dan misi organisasi. Oleh karena itu, tenaga kerja perlu dipacu kinerjanya, mengingat sumber daya manusialah yang mengatur atau mengelola sumber daya yang lainnya. Pencapaian kinerja pegawai yang baik, perlu diupayakan faktor-faktor untuk mendukung tenaga kerja agar dapat bekerja secara optimal.

Kinerja pada umumnya diartikan sebagai kesuksesan seseorang didalam melaksanakan suatu pekerjaan. Kinerja pegawai merupakan hasil kerja yang dicapai seseorang dalam melaksanakan tugas-tugas yang di bebankan kepadanya. Kinerja pegawai meliputi kualitas dan kuantitas output serta keandalan dalam bekerja. Pegawai dapat bekerja dengan 
baik bila memiliki kinerja yang tinggi sehingga dapat menghasilkan kerja yang baik pula. Dengan adanya kinerja yang tinggi yang dimiliki pegawai, diharapkan tujuan organisasi dapat tercapai. Sebaliknya, tujuan organisasi susah atau bahkan tidak akan tercapai bila pegawai bekerja tidak memiliki kinerja yang baik sehingga tidak dapat menghasilkan kerja yang baik pula. Kompensasi merupakan salah satu strategi manajemen sumber daya manusia untuk menciptaka keselarasan kerja antara staf dengan pimpinan Organisasi dalam mencapai tujuan dan sasaran yang sudah ditetapkan.

Ada berbagai cara yang dapat ditempuh untuk meningkatkan kinerja pegawai, yaitu antara lain dengan jalan menerapkan secara tegas disiplin kerja pegawai serta membuka kesempatan kepada pegawai untuk pengembangan karir. Sejalan dengan perkembangan suatu organisasi, maka diperlukan usaha-usaha untuk meningkatkan keterampilan dan profesionalisme pegawai dalam memberikan perhatian dan pembinaan yang pada akhirnya diharapkan dapat mengembangkan karir pegawai.

Pengembangan karir seorang pegawai perlu dilakukan karena seorang pegawai bekerja dalam suatu organisasi tidak hanya ingin memperoleh apa yang dipunyainya, tetapi juga mengharapkan ada perubahan, ada kemajuan dan kesempatan yang diberikan kepadanya untuk maju ke tingkat yang lebih tinggi dan lebih baik. Dengan demikian, semakin baik penerapan pengembangan karir di Organisasi akan berpengaruh pada peningkatan kinerja pegawai meningkat atau komitmen yang tinggi dan kepuasan kerja yang tinggi maka akan dapat meningkatkan kinerja seseorang.

Pengembangan karir seorang pegawai perlu dilakukan karena seorang pegawai bekerja dalam suatu organisasi tidak hanya ingin memperoleh apa yang dipunyainya, tetapi juga mengharapkan ada perubahan, ada kemajuan dan kesempatan yang diberikan kepadanya untuk maju ke tingkat yang lebih tinggi dan lebih baik. Dengan demikian, semakin baik penerapan pengembangan karir berpengaruh pada peningkatan kinerja pegawai. Namun pada kenyataanya, yang sering terjadi pada instansi pemerintah adalah pengembangan karir dipandang sebagai hal yang kurang diprioritaskan dalam agenda pengembangan sumber daya manusia.

Berdasarkan hasil observasi yang penulis lakukan ditemukan fakta bahwa kinerja pegawai Balai Besar Wilayah Sungai Mesuji Sekampung masih rendah. Hal ini terlihat dari pencapaian target yang tidak terealisir secara keseluruhan Balai Besar Wilayah Sungai Mesuji Sekampung. Balai Besar Wilayah Sungai Mesuji Sekampung dalam melaksanakan pencapaian tujuan organisasi menghadapi kendala yang berkaitan dengan kinerja pegawai, di mana masih ada kegiatan pada tahun 2018 yang tidak selesai 100\%

\section{KAJIAN TEORI}

\section{Pengembangan Karir}

Pengembangan karir terdiri atas semua pekerjaan yang dipegang seseorang selama kehidupan pekerjaannya. Untuk beberapa orang, pekerjaan-pekerjaan tersebut sebagai bagian dari sebuah perencanaan yang disiapkan secara terarah sedangkan untuk yang lainnya bisa jadi sebuah karir dikatakan sebagai peristiwa keberuntungan. Keputusan karir memang hendaknya didasarkan pada ukuran objektif tetapi tidak jarang muncul karena unsur subjektivitasnya dari kalangan otoritas tertentu. Uraian pekerjaan dan spesifikasi pekerjaan yang jelas di dalam Organisasi akan dapat menghindari adanya 
keputusan karir yang bersifat subjektif. Nawawi (2009:82) menyatakan bahwa uraian pekerjaan dan spesifikasi pekerjaan yang merupakan hasil dari analisis pekerjaan mempunyai manfaat:

1. Pekerja yang tidak mampu memenuhi persyaratan fungsi esensial pekerjaan dengan kesadaran sendiri (tanpa paksaan) harus bersedia mengundurkan diri daripada menghadapi resiko yang dapat merugikan diri sendiri, Organisasi dan lingkungan sekitarnya,

2. Para pekerja yang ternyata memenuhi persyaratan fungsi esensial perjalanan berhak memperoleh kompensasi dan akomodasi yang layak melebihi pekerja lainnya. Sedangkan para manajer berkewajiban memenuhinya agar tidak kehilangan tenaga kerja yang langka dan mampu meningkatkan kompotitif organisasi.

Dari ketiga pengertian ini dapat disimpulkan bahwa pengembangan karir harus diusahakan secara aktif. Tidak boleh hanya ditunggu tetapi harus diperjuangkan. Mangkuprawira (2012:40) menyatakan bahwa .komponen utama dari karir terdiri dari:

1. Alur karir adalah pola pekerjaan yang berurutan yang membentuk karir seseorang.

2. Tujuan karir merupakan pernyataan tentang posisi masa depan di mana seseorang berupaya mencapainya sebagai bagian dari karir hidupnya. Tujuan ini menunjukkan kedudukan seseorang sepanjang karir pekerjaannya.

3. Perencanaan karir merupakan proses di mana seseorang menyeleksi tujuan karir dan arus karir untuk mencapai tujuan tersebut.

4. Pengembangan karir meliputi perbaikan-perbaikan personal yang dilakukan untuk mencapai rencana dan tujuan karir.
Mangkuprawira

(2012:46)

menyatakan bahwa keterlibatan departemen sumber daya manusia dalam perencanaan dan pengembangan karir pegawai memiliki banyak manfaat, yaitu:

1. Meluruskan strategi dan syaratsyarat internal penempatan staf Dengan membantu pegawai pegawai melalui perencanaan karir, departemen SDM dapat mempersiapkan lebih baik untuk partisipasi pekerjaan terbuka yang dituangkan dalam perencanaan SDM. Hasilnya adalah terpenuhinya kebutuhan Organisasi dengan pegawai yang memiliki bakat dan kemampuan untuk menduduki posisi tertentu.

2. Mengembangkan pegawai yang dapat dipromosikan. Membantu dalam mengembangkan pasokan internal bakat-bakat pegawai yang dapat dipromosikan untuk memenuhi posisi yang terbuka, misalnya karena adanya pegawai yang pensiun, mengundurkan diri dan jika terjadi pertumbuhan Organisasi .

3. Memfasilitasi pengembangan karir tingkat internasional Pada Organisasi yang mengglobal, perencanaan karir digunakan untuk membantu mengidentifikasi dan menyiapkan pegawai asing atau pegawai domestik yang memiliki daya saing tinggi.

4. Membantu pekerja yang memiliki keragaman tertentu. Ketika diberi bantuan perencanaan karir, para pekerja denga latar belakang berbeda dapat belajar tentang harapan-harapan Organisasi untuk pengembangan diri.

5. Memperkecil derajat perputaran pegawai. Perhatian dan kepedulian yang meningkat untuk karir para individu pegawai dapat 
meningkatkan kesetiaan pegawai terhadap Organisasi dan memperkecil terjadinya perputaran pegawai .

6. Membuka jalan bagi pegawai potensial. Perencanaan karir mendorong para pegawai untuk menunjukkan kemampuan potensial mereka lebih terbuka lagi karena mereka memiliki tujuan karir yang spesifik. Hal ini tidak hanya menyiapkan pegawai untuk memenuhi peluang masa depan tetapi dapat mengarahkan ke kinerja yang lebih baik bagi mereka yang sedang memegang jabatan.

\section{Kinerja Pegawai}

Setiap pegawai dalam organisasi dituntut untuk memberikan kontribusi positif melalui kinerja yang baik, mengingat kinerja organisasi tergantung pada kinerja pegawainya. Kinerja adalah tingkat terhadapnya para pegawai mencapai persyaratan pekerjaan secara efisien dan efektif. Kinerja pegawai merupakan prestasi kerja, yakni perbandingan antara hasil kerja yang dapat dilihat secara nyata dengan standar kerja yang telah ditetapkan organisasi. Robbins (2016:56) mendefinisikan kinerja yaitu suatu hasil yang dicapai oleh pegawai.

\section{METODE PENELITIAN}

\section{Objek Penelitian}

Objek dalam penelitian ini adalah pegawai Kementerian Pekerjaan Umum di lingkungan Balai Besar Wilayah Sungai Mesuji Sekampung yang beralamat di Jalan Gatot Subroto Nomor 57 Garuntang Bandar Lampung. Waktu penelitian dilakukan antara Bulan Mei sampai dengan Bulan Juni 2019.

\section{Metode dan Teknik Pengumpulan Data}

Data yang di perlukan dalam penelitian dapat berupa data sekunder dan data primer yang di kumpulkan dengan cara sebagai berikut :

a. Data Primer

Data Primer merupakan data yang diperoleh langsung di lokasi penelitian, tanpa perantara orang atau lembaga lain sebagai pihak ketiga.

b. Data Sekunder

Data Sekunder merupakan data yang diperoleh melalui orang lain yang berhubungan dengan permasalahan yang dipecahkan. Data sekunder ini diperoleh melalui cara studi dokumenter yaitu mengumpulkan dan mempelajari brosurbrosur serta dokumen organisasi.

\section{Sampel dan Populasi}

Menurut Arikunto (2012:105), populasi merupakan keseluruhan obyek penelitian atau semua elemen yang ada dalam wilayah penelitian. Populasi penelitian untuk tesis ini dipilih secara sengaja (purposive population). Adapun jumlah populasi yang ada di lokasi penelitian adalah sebanyak 526 orang pegawai.

Teknik pangembilan sampel dalam penelitian ini penulis merujuk pendapat Arikunto (2012:107) yang menyatakan apabila dalam suatu penelitian terhadap subjek yang kurang dari 100, maka populasi akan diambil seluruhnya sebagai sampel, sedangkan apabila subjek lebih dari 100, maka sampel yang diambil antara $10 \%$ $25 \%$ dari seluruh populasi yang ada. Berdasarkan pendapat diatas, maka penulis mengambil $10 \%$ dari seluruh pegawai Balai Besar Wilayah Sungai Mesuji Sekampung 
sehingga sampel ditetapkan menjadi 53 orang pegawai.

\section{Metode Analisis Data}

\section{Analisis Regresi}

Menurut Sugiyono (2013:261), dalam statistik deskriptif dapat dilakukan mencari kuatnya hubungan antara variabel melalui analisis korelasi, melakukan prediksi dengan analisis regresi, dan membuat perbandingan dengan membandingkan rata-rata data sampel atau populasi. Analisis regresi digunakan untuk memprediksi seberapa jauh perubahan nilai variabel dependen,bila nilai variabel independen dimanipulasi/dirubah- rubah atau dinaik turunkan. Rumus regresi linear sederhana yang digunakan dalam penelitian ini adalah sebagai berikut:

$$
Y=a+b X+e
$$

Keterangan :

$$
\begin{aligned}
& \mathrm{Y}=\text { Variabel dependen } \\
& \mathrm{A}=\text { Intercept (harga konstan) } \\
& \mathrm{B}=\text { Koefisien regresi } \\
& \mathrm{X}=\text { Variabel independen } \\
& \mathrm{E}=\text { Error }
\end{aligned}
$$

(Sugiyono, 2013:261)

Untuk mengetahui keeratan hubungan mutasi dengan semangat kerja pegawai BPKAD Kabupaten Pesawaran, penulis menggunakan pedoman koefision korelatif adalah :

Tabel 1. Pedoman untuk memberikan interpretasi terhadap koefisien korelasi

\begin{tabular}{|l|l|}
\hline Interval Koefisien & Tingkat Hubungan \\
\hline $0,000-0,199$ & Sangat Rendah \\
$0,200-0,399$ & Rendah Sedang \\
$0,400-0,599$ & Kuat \\
$0,600-0,799$ & Sangat kuat \\
$0,800-1,000$ & \\
\hline
\end{tabular}

Sumber : Supriyanto (2008:168)

\section{Koefisien Determinasi (R2)}

Koefisien determinasi merupakan alat untuk mengukur seberapa jauh kemampuan model dalam menerangkan variasi variabel dependen. Koefisien determinasi yang mendekati atau berarti variabel-variabel independen memberikan hampir semua informasi yang dibutuhkan untuk memprediksi variabel dependen. Penggunaan $\mathrm{R}$ square adalah bisa terhadap jumlah variabel independen yang dimasukkan ke dalam model. Setiap tambahan variabel independen ke dalam model, maka $\mathrm{R}$ square pasti meningkat tidak perduli apakah variabel independen tersebut berpengaruh secara signifikan atau tidak. Tidak seperti $\mathrm{R}$ square, nilai adjusted $\mathrm{R}$ square dapat naik atau turun apabila terdapat tambahan variabel independen kedalam model. Oleh karena itu sebaiknya digunakan nilai adjusted $\mathrm{R}$ untuk mengevaluasi model regresi terbaik.

\section{Uji Hipotesis}

Selanjutnya untuk menguji pengaruh secara sendiri-sendiri atau partial antara X terhadap Y digunakan Uji t dengan keterangan sebagai berikut:

a. Jika $t_{\text {hitung }}>t_{\text {tabel }}$ maka Ha diterima dan Ho ditolak

b. Jika $t_{\text {hitung }}<t_{\text {tabel }}$ maka Ha ditolak dan Ho diterima

Taraf signifikan dalam penelitian ini digunakan $\mathrm{a}=0,05$ atau $5 \%$ Yang dimakasud dengan Hipotesis nol (Ho) dan Hipotesis Alternatif (Ha) adalah:

Ho $=$ r1 $<0=$ Berarti tidak ada pengaruh antara tunjangan kinerja terhadap disiplin kerja pegawai

$\mathrm{Ha}=\mathrm{r} 1>0=$ Berarti ada pengaruh antara tunjangan kinerja terhadap disiplin kerja pegawai. 


\section{HASIL DAN PEMBAHASAN}

\section{Pengujian Validitas}

Pengolahan data dengan menggunakan peralatan matematis melalui program SPSS 21.0 diperoleh nilai koefisien korelasi ( $\mathrm{r}$ hitung) untuk masingmasing variabel bahwa nilai korelasi antar skor item dengan skor total item untuk 10 butir pernyataan, memiliki nilai korelasi yang lebih besar dari pada nilai korelasi $\mathrm{r}$ tabel pada taraf signifikan @ = 0,05 dengan df 53 yaitu sebesar 0,266. Dengan demikian dapat disimpulkan bahwa butir-butir soal tersebut seluruhnya valid.

Hasil pengujian validitas dengan aplikasi SPSS 21.00, rekapitulasi validitas pengembangan karir adalah sebagai berikut :

Tabel Validitas Pengembangan karir (X)

\begin{tabular}{|l|l|l|l|}
\hline $\begin{array}{l}\text { No } \\
\text { Item }\end{array}$ & Nilai $r$ hit & Nilai $r$ tabel & Keterangan \\
\hline 1 & 0.522 & 0.266 & Valid \\
\hline 2 & 0.495 & 0.266 & Valid \\
\hline 3 & 0.642 & 0.266 & Valid \\
\hline 4 & 0.605 & 0.266 & Valid \\
\hline 5 & 0.403 & 0.266 & Valid \\
\hline 6 & 0.331 & 0.266 & Valid \\
\hline 7 & 0.341 & 0.266 & Valid \\
\hline 8 & 0.413 & 0.266 & Valid \\
\hline 9 & 0.311 & 0.266 & Valid \\
\hline 10 & 0.371 & 0.266 & Valid \\
\hline
\end{tabular}

Berdasarkan hasil uji validitas pengembangan karir maka item angket pengembangan karir secara keseluruhan dinyatakan valid.

Berdasarkan hasil pengujian validitas dengan aplikasi SPSS rekapitulasi hasil pengujian validitas kinerja pegawai adalah sebagai berikut:

Tabel Validitas Kinerja pegawai (Y)

\begin{tabular}{|l|l|l|l|}
\hline Item test & Nilai $r$ hit & Nilai $r$ tabel & Keterangan \\
\hline 1 & 0.461 & 0.266 & Valid \\
\hline 2 & 0.309 & 0.266 & Valid \\
\hline 3 & 0.520 & 0.266 & Valid \\
\hline 4 & 0.648 & 0.266 & Valid \\
\hline 5 & 0.335 & 0.266 & Valid \\
\hline 6 & 0.792 & 0.266 & Valid \\
\hline 7 & 0.510 & 0.266 & Valid \\
\hline 8 & 0.335 & 0.266 & Valid \\
\hline 9 & 0.474 & 0.266 & Valid \\
\hline 10 & 0.343 & 0.266 & Valid \\
\hline
\end{tabular}

Berdasarkan hasil uji validitas variabel kinerja, maka item angket secara keseluruhan dinyatakan valid.

\section{Pengujian Reliabilitas}

\section{Variabel Pengembangan karir}

Instrumen variabel pengembangan karir, juga ternyata reliabel semuanya (10 item), karena cronbach's alpha total sebesar 0,593 diatas nilai $r$ product moment pada $n$ $=53$ dan $\alpha 5 \%$ sebesar0.266 dan diatas nilai cronbach's alpha per item, seperti terlihat pada tabel berikut :

Tabel Reliabilitas Pengembangan karir

\begin{tabular}{|l|l|}
\hline Cronbach's Alpha & N of Items \\
\hline 0.593 & 10 \\
\hline
\end{tabular}

\section{Uji hipotesis (t)}

Uji $\mathrm{t}$ digunakan untuk menguji signifikansi pengaruh antara variabel $\mathrm{X}$ dan $\mathrm{Y}$, apakah variabel $\mathrm{X}$ (pengembangan karir) benar-benar berpengaruh terhadap variabel Y (kinerja pegawai) secara parsial. Untuk menguji pengaruh pengembangan karir secara parsial terhadap kinerja pegawai Balai Besar Wilayah Sungai Mesuji Sekampung digunakan Uji statistic $\mathrm{t}$ ( uji t). Apabila nilai $\mathrm{t}$ hitung $>\mathrm{t}$ tabel maka Ho ditolak dan $\mathrm{Ha}$ diterima. 
Sebaliknya apabila nilai $\mathrm{t}$ htung $<$ nilai $\mathrm{t}$ tabel maka Ho diterima dan Ha ditolak. Hasil pengujian hipotesis secara parsial dapat dilihat pada tabel berikut ini.

Tabel. Pengujian Hipotesis Pengaruh Pengembangan karir terhadap Kinerja pegawai

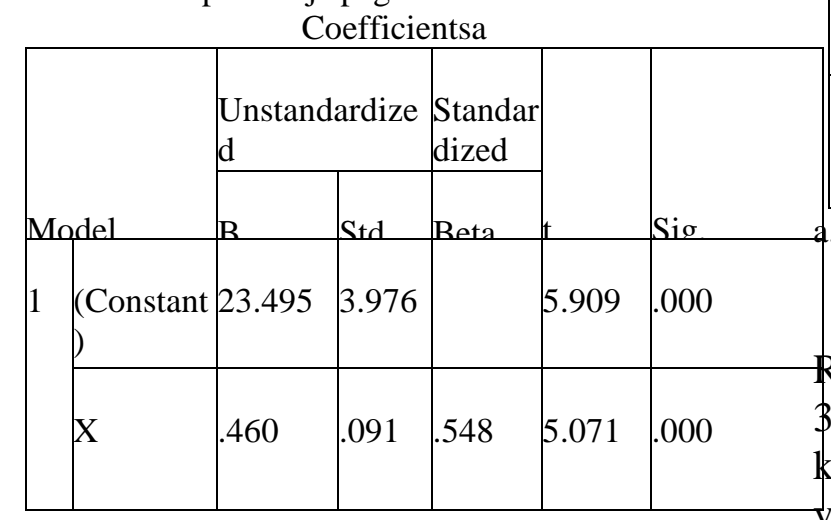

a. Dependent Variable: Y

Nilai t hitung untuk pengembangan karir yaitu 5.071 dengan konstanta 5.909, pada $t$ tabel dengan db 53 dan taraf signifikan 0.05 diperoleh 1.67 karena $t$ hitung $>\mathrm{t}$ tabel maka Ha diterima. Signifikasi variabel pengembangan karir adalah 0.000 yang berarti probabilitas 0.000 , karena probabilitas kurang dari 0,05 maka Ha diterima, artinya pengembangan karir berpengaruh terhadap kinerja pegawai. Koefisien arah regresi antara pengembangan karir terhadap kinerja pegawai sebesar 0.460 dengan konstanta sebesar 23.495. Dengan demikian, persamaan regeresinya adalah $\mathrm{Y}=23.495+$ 0.460X, yang mengandung arti bahwa setiap kenaikan variabel pengembangan karir 1 satuan akan diikuti dengan kenaikan kinerja pegawai Balai Besar Wilayah Sungai Mesuji Sekampung sebesar 0,460 satuan. Nilai koefisien adalah sebesar 23.495 yang mempunyai arti apabila tidak terdapat faktor pengembangan karir $(X=0)$, diperkirakan kinerja pegawai tetap sebesar 23.495 satuan.

Untuk mengetahui seberapa jauh variabel pengembangan karir menjelaskan variabel kinerja pegawai dapat dilihat dari nilai koefisien determinasi (R Square) pada

Tabel Hasil Uji Koefisien Determinasi Model Summary

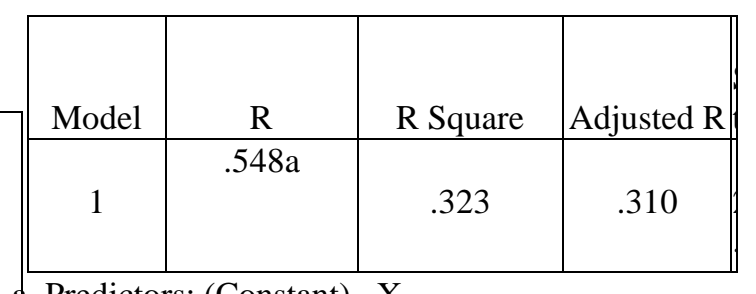

Predictors: (Constant), X

Dari tabel 3.10 diatas diketahui bahwa $\mathbb{R}$ Square sebesar 0.323 artinya sebesar \$2,2 \% variasi perubahan variabel terikat kinerja pegawai mampu dijelaskan oleh variabel bebas pengembangan karir sedangkan sisanya $67,8 \%$ lagi dijelaskan faktor-faktor lain yang tidak diteliti dalam penelitian ini. Dengan demikian, tujuan penelitian yang berbunyi untuk mengetahui besarnya pengaruh pengembangan karir terhadap kinerja pegawai dapat diwujudkan dengan besarnya kontribusi antara pengembangan karir terhadap kinerja pegawai sebesar $32,2 \%$.

\section{KESIMPULAN DAN SARAN}

\section{Kesimpulan}

Berdasarkan simpulan hasil analisis dan temuan-temuan yang diperoleh, maka dapat disimpulkan bahwa :

Nilai R Square sebesar 0.323 artinya sebesar 32,2 \% variasi perubahan variabel terikat kinerja pegawai mampu dijelaskan oleh variabel bebas pengembangan karir sedangkan sisanya $67,8 \%$ lagi dijelaskan faktor- faktor lain yang tidak diteliti dalam penelitian ini. Dengan demikian, tujuan penelitian yang berbunyi untuk mengetahui besarnya pengaruh pengembangan karir terhadap kinerja pegawai dapat diwujudkan dengan 
besarnya kontribusi antara pengembangan karir terhadap kinerja pegawai sebesar $32,2 \%$.

\section{Saran}

Berdasarkan hasil penelitian, maka didapat beberapa saran sebagai berikut:

1. Kepada unsure pimpinan diharapkan dapat lebih memotivasi pegawai untuk melaksanakan pengembangan karir dengan memberikan arahan kepada seluruh pegawai untuk meningkatkan kualifikasi dan keterampilan kerja sehingga di masa yang akan datang pegawai siap untuk menduduki jabatan tertentu yang dibutuhkan oleh instansi.

2. Kepada pegawai harus lebih menghargai jam kerja dengan berusaha keras untuk tidak membuang-buang waktu percuma pada jam kerja, terlebih lagi berada di luar kantor untuk mengurus keperluan pribadi. Untuk menyikapi permasalahan ini maka setiap pimpinan unit kerja dapat menjalankan fungsi pengawasan melekat kepada bawahan langsung dan sanggup memberi teguran kepada bawahan yang terlihat santai pada jam kerja.

\section{DAFTAR PUSTAKA}

Martoyo, Susilo. 2000. Manajemen Sumber Daya Manusia. Jogjakarta: PT BPFE.

Moeheriono. 2012. Pengukuran Kinerja Berbasis Kompetensi. Jakarta: Raja Grafindo Persada.

Panggabean, Mutiara S.. 2004. Manajemen Sumber Daya Manusia. Bogor : Ghalia Indonesia.
Pasolong, Harbani. 2010. Teori Administrasi Publik. Bandung: Alfabeta.

Rivai, Veithzal, Dato' Ahmad Fawzi, Mohd. Basri. 2005. Performance Appraisal, sistem yang tepat untuk menilai kinerja karyawan dan meningkatkan daya saing perusahaan. Jakarta:Raja Grafindo Persada

Sastrohadiwiryo, Siswanto. 2003. Manajemen Tenaga Kerja Indonesia, Pendekatan Administrasi dan Operasional. Jakarta: Bumi Aksara.

Sedarmayanti. 2012. Manajemen Sumber Daya Manusia. Jakarta : Refika Aditama Eresco.

Siagian, Sondang P. 2012. Patologi Birokrasi: Analisis, Identifikasi, dan Terapinya. Jakarta: Ghalia Indonesia.

Simamora, Henry. 2003. Manajemen Sumber Daya Manusia. Edisi 1. Yogyakarta: STIE YKPN Yogyakarta.

Grogoruis, Chandra. (2015;155). Pemasaran Sentrategij, Edisi II. Jakarta: ISBN.

Simamora, Henry. 2003. Manajemen Sumber Daya Manusia. Edisi 1. Yogyakarta: STIE YKPN Yogyakarta.

Husein Umar dalam Sunyoto. 2012. Manajemen Sumber Daya Manusia Strategik. Jakarta: Ghalia Indonesia. 